\title{
Expression of calcitonin gene-related peptide and pulp sensitivity tests in irreversible pulpitis
}

\author{
Brenda Eréndida CASTILLO-SILVA ${ }^{(a)}$ \\ Verónica MARTÍNEZ-JIMÉNEZ(a) (i) \\ Gabriel Alejandro MARTíNEZ- \\ CASTAÑÓN ${ }^{(b)}$ \\ Carlo Eduardo MEDINA-SOLÍS(c) \\ Eva Concepción AGUIRRE-LÓPEZ(a) \\ Jesús Ramón CASTILO-HERNÁNDEZ ${ }^{(b)}$ (i) \\ Nereyda NIÑO-MARTíNEZ(b) (D) \\ Nuria PATIÑO-MARÍN(a) \\ (a) University of San Luis Potosí, Program \\ of Doctorate in Dental Sciences, \\ Department of Clinical Research, San \\ Luis Potosí, SLP, Mexico. \\ (b) University of San Luis Potosí, Program of \\ Doctorate in Dental Sciences, San Luis \\ Potosí, SLP, Mexico. \\ (c)Autonomous University of The State of Hidalgo, \\ Institute of Health Sciences, Department of \\ Dentistry, Pachuca, Hidalgo, Mexico.
}

Declaration of Interests: The authors certify that they have no commercial or associative interest that represents a conflict of interest in connection with the manuscript.

\section{Corresponding Author:}

Nuria Patiño-Marín

E-mail:1nuriapm@gmail.com

hitps://doi.org/10.1590/1807-3107bor-2019.vol33.0077

Submitted: Mar 6, 2019

Accepted for publication: June 11, 2019

Last revision: June 27, 2019
Abstract: The aim of the present study was to identify the relationship between the expression of calcitonin gene-related peptide (CGRP) and the responses of pulp sensitivity tests in healthy pulps and irreversible pulps by performing a cross-sectional study on patients. Two hundred subjects were evaluated. A total of 75 subjects complied with the criteria. The participants were divided into two groups: a) Healthy pulp (subjects [ $\mathrm{n}=35$ ] having posterior teeth with clinically normal pulp tissue), and b) Irreversible pulpitis (subjects [ $n=40$ ] having posterior teeth with irreversible pulpitis). All participants were evaluated using the following variables: a) medical and dental history, b) pulp sensitivity tests, c) expression of CGRP by the enzyme-linked immunosorbent assay (ELISA), and d) expression levels of mRNA CGRP and mRNA CGRP receptor genes. We determined that the responses of the cold test between 4 and $\geq 12 \mathrm{~s}$ presented a higher average of the expression of CGRP in the group having irreversible pulpitis $(p=0.0001)$. When we compared the groups with the value of the electrical impulse, we found statistically significant differences $(p=0.0001)$, observing positive responses to the test with electrical impulses of 7 to 10, with an average of $72.15 \mathrm{ng} / \mathrm{mL}$ of CGRP in the irreversible pulpitis group. High values of CGRP expression were observed in that group in the responses of pulp sensitivity.

Keywords: Calcitonin Gene-Related Peptide; Dental pulp test.

\section{Introduction}

Dental pulp inflammation (pulpitis) is a complicated process that involves various nervous and vascular reactions. Neuropeptides are actively involved in homeostatic regulation both under normal conditions and during pulp inflammation by controlling its blood flow and regulating the later stages of inflammation and repairing processes. ${ }^{1}$ Calcitonin gene-related peptide (CGRP) is a neuropeptide located in the C-type fibers of pulp tissue, participating in neurotropic and neurotrophic activities, regulating antigen presence within the immune system, and acting as an endogenous vasodilator. ${ }^{2}$ This neuropeptide also interacts with different immunoregulator cell populations, such as macrophages, modulating their function and inducing the release of inflammatory mediators including cytokines, prostaglandins, and 
thromboxanes. ${ }^{3}$ Measures such as medical and dental histories, clinical examinations, specific pulp tests, and radiographic analyses are necessary to diagnose pulpitis. Pulp sensitivity tests are frequently used in clinical practice because of their simplicity and low cost. However, researchers have published the following limitations regarding these tests: a) the tests report subjective results and measure only pulpal nerve responses and not pulpal blood flow, and b) some pathologies, restorations, and tooth characteristics are associated with false results. ${ }^{4}$ Even with their limitations, pulp sensitivity tests are useful in diseased pulps because the responses in diseased pulps are different from those in healthy pulps. ${ }^{4}$ By increasing the understanding of the interrelationships between nervous and vascular reactions and the clinical signs and symptoms of dental pulp inflammation, we might be able to devise tools or strategies to complement the diagnosis. ${ }^{5,6,7}$ Therefore, the aim of this study was to identify the relationship between the expression of CGRP and the responses of pulp sensitivity tests in healthy pulps and irreversible pulps.

\section{Methodology}

A cross-sectional study was performed from December 2015 to May 2018 in patients referred to the University of San Luis Potosí, Mexico, for either endodontic therapy or extraction of teeth for orthodontic reasons. All methods were carried out in accordance with relevant guidelines and regulations on humans. Following the ethical principles in the Helsinki Declaration, an informed and voluntary written consent was obtained from the patients before start of the study. The study was approved by the Research Ethics Committee of the Faculty of Dentistry, San Luis Potosí University, Mexico.

\section{Study population}

Two hundred subjects were evaluated in the study. A total of 75 subjects matched the following criteria:

Inclusion: a) no systemic diseases; b) both sexes; c) aged 17-40 years; d) no history of allergies; e) nonsmokers; f) subjects with posterior teeth (premolars) with clinically normal pulp tissue indicated for exaction for orthodontic purposes, and g) subjects with posterior teeth (premolars and molars) with a diagnosis of irreversible pulpitis.

Exclusion: a) pregnancy; b) history of trauma during the past 6 months; $c$ ) subjects having teeth with full surface crowns; d) subjects having restorations on surfaces under evaluation; e) cavity access; f) subjects having calcified root canals, and (7) subjects having incomplete root formation. ${ }^{8,9,10}$

\section{Calculation of sample size}

Sample size calculation was based on a previous study $^{11}$ for a design of comparison of means. The minimum sample size was calculated to be 20 participants for each group with a power of 0.80 and a significance level of 0.05 .

Medical and dental histories were taken on all participants. An investigator recorded the medical history (including details of any medication taken within the past 6 months). The dental history included past and recent treatments, major pains (onset, duration, frequency, intensity, and location of pain), clinical evaluation (caries, restorations, enamel loss [abrasion, attrition, and fractures]), radiographic analysis (size and shape of the pulp chamber and root canals, radiolucent lesions, and thickened periodontal ligaments), and a periodontal evaluation (periodontal probing, gingivitis, and abscesses). ${ }^{10}$

\section{Study groups}

The subjects were divided into two groups:

(1) Control.Subjects with posterior teeth (premolars) with clinically normal pulp tissue indicated for extraction for orthodontic purposes, without enamel loss, without restorations or caries, without periodontal disease, asymptomatic, and without radiographic evidence of periapical pathology.

(2) Irreversible pulpitis. Subjects with posterior teeth (premolars and molars) diagnosed with irreversible pulpitis. Patients had moderate-to-severe spontaneous pain of approximately 24-h duration, and they had not taken any anti-inflammatory medications, had either a normal or a hypersensitive reaction to percussion, and had no radiographic evidence of periradicular pathosis. ${ }^{1,11,12}$ 


\section{Pulp sensitivity tests}

\section{Cold pulp testing}

The teeth were isolated using cotton rolls and dried with cotton gauze. ${ }^{13} \mathrm{~A}$ clinical researcher sprayed a No. 2 cotton pellet with a refrigerant spray $(1,1,1$, 2-tetrafluoroethane, Hygienic Endo-Ice Green [Endo-Ice]; Coltene Whaledent, Cuyahoga Falls, USA), ${ }^{9,10,14}$ which was then placed onto the tooth crown (on the buccal middle third) for $25 \mathrm{~s}$ or until the participant raised a hand to indicate a cold sensation. The results of the test were reported in seconds. First time evaluation (FT) was the number of seconds from the application of the stimulus until the participant raised a hand. The second time evaluation (ST) was the number of seconds from the removal of the stimulus until the sensation disappeared. ${ }^{10}$

\section{Electric pulp testing}

A second researcher used an electric pulp tester (Parkell Electronics Division, Farmingdale, USA) to apply an electrical impulse on the buccal middle third of each tooth. The vitalometer was used in accordance with the manufacturer's instructions (monopolar mode with anodal electrode probe tip and a diameter of $2 \mathrm{~mm}$ ). On a scale of $0-10$ units, the rate of increase was recorded every $5 \mathrm{~s}$ for all study subjects. ${ }^{15,16}$

\section{Applying the tests}

The tests were performed by two researchers (to obtain independent results) who were blinded to the subjects' clinical signs and symptoms, dental history, periodontal status, and radiographic findings. All teeth were tested (assigned randomly for each subject) using the two methods (cold test and electric test). The researchers allowed at least 5 min to elapse after each pulp test. Each participant was instructed to raise a hand the moment a sensation was felt during testing and to lower the hand the moment the sensation disappeared.

\section{Procedures for obtaining pulp samples}

Pulp samples from teeth with irreversible pulpitis

After completing the tests, we performed endodontic treatment while the patients were anesthetized with $2 \%$ lidocaine and 1:100,000 diluted epinephrine. The teeth were isolated with a rubber dam, and the access cavity was completed. Finally, the pulp tissue was extracted with a sterile barbed broach file.

Samples of clinically normal pulp (teeth indicated for exaction for orthodontic purposes)

The teeth were anesthetized as for irreversible pulpitis, and all extractions were completed in less than $2.5 \mathrm{~min}$. After this, the extracted teeth were washed with $5.25 \%$ sodium hypochlorite to eliminate remnants of the periodontal ligament. The teeth were then placed on a sterile tray and separated using a sterile cylindrical diamond bur in a high-speed handpiece irrigated with saline solution. The pulp tissue was removed using a sterile endodontic excavator.

\section{Expression of the CGRP by the enzyme-linked immunosorbent assay (ELISA) and expression levels of mRNA CGRP and $m R N A$ CGRP receptor genes by real-time PCR}

\section{Expression of the CGRP by the enzyme-linked immunosorbent assay (ELISA)}

a. Extraction of proteins using TRIzol: Dental pulps were resuspended in $0.5 \mathrm{~mL}$ TRIzol (Sigma-Aldrich Chemical Co, St. Louis, USA) and the proteins were precipitated with isopropanol. The protein pellets were washed three times with $0.3 \mathrm{M}$ guanidine hydrochloride (Sigma-Aldrich), 95\% ethanol (Sigma-Aldrich) and were then centrifuged and washed with absolute ethanol (Sigma-Aldrich). Protein pellets were dissolved in $50 \mu \mathrm{L}$ of urea-CHAPS (9.5 M urea/2\% CHAPS; Sigma-Aldrich). Protein quantification was performed with bicinchoninic acid microplate assay. Protein solutions were aliquoted and stored at $-20^{\circ} \mathrm{C}$ before use.

b. ELISA determination of CGRP: ELISA, using a commercially available kit (Phoenix Pharmaceuticals, Inc, Burlingame, USA), was employed to measure the concentration of CGRP 
in the dental pulps. The assay was performed according to the manufacturer's instructions with a detection range $0.100 \mathrm{ng} / \mathrm{mL}$. In the assays, we used $1 \mu \mathrm{g}$ of total protein extracted from the dental pulps. All samples were assayed in duplicate, and mean values were calculated. Intensity of the color determined by spectrophotometry was proportional to the amount of the human CGRP present in each well during immunological incubation.

\section{Expression levels of mRNA CGRP and mRNA}

CGRP receptor genes by real-time PCR

a. Isolation of total RNA using TRIzol: Total RNA was extracted from the frozen pulp tissues using $0.5 \mathrm{~mL}$ TRIzol reagent (Sigma-Aldrich); all tissues were homogenized, and then the DNA, RNA, and proteins were removed. The RNA was dissolved in $30 \mu \mathrm{L}$ of diethylpyrocarbonatetreated water and stored at $-20^{\circ} \mathrm{C}$ until use. The purity and yield of total RNA was measured spectrophotometrically at 260 and $280 \mathrm{~nm}$ using a NanoDrop spectrophotometer (Thermo Scientific NanoDrop 2000, Thermo Fisher Scientific, Wilmington, New Hanover, USA). The absorption ratio (260:280 nm) was between 1.6 and 1.8. Finally, the samples were subjected to gel electrophoresis and stained with ethidium bromide to verify the integrity of the $18 \mathrm{~S}$ and $28 \mathrm{~S}$ ribosomal RNA.

b. Real time q-PCR assays to measure mRNA expression levels of CGRP and CGRP receptor genes: We used 5-10 $\mu \mathrm{g}$ of total RNA to obtain complementary DNA (cDNA) using a High Capacity cDNA Reverse Transcription Kit (Applied Biosystems, Bio-Rad Laboratories Inc, San Francisco, USA). cDNA was employed to measure CGRP and receptor messenger RNA (mRNA) expression using specific primers by qRT-PCR. SybrGreen; $100 \mathrm{ng}$ of cDNA was used to perform each PCR reaction (Bio-Rad) in an RT thermocycler CFX96 Real-Time System (Bio-Rad). The results obtained were analyzed using the $2^{-\triangle \Delta C q}$ method. The GAPDH gene was used as an internal control to normalize the gene expression values of the CGRP and
CGRP receptor genes $(\Delta \mathrm{Cq}$; relative gene expression of CGRP/GAPDH). The primers used to amplify the genes were designed by bioinformatic analyses of the reported sequences in the NCBI (PUBMED), employing $A p E$ analysis software. The sequences of primers used in the study were CGRP, forward 5'-GCCTGTGACACTGCCACCTG-3; reverse 5'AAAGGCTTTGGAACCCACAT-3'; and CGRP receptor, forward 5-TCT GGT TCT CTT GCC TTT TTT-3; and reverse 5'-GTC CAT GTT CTG TTG CTT GCT-3.17,18

\section{Statistical analysis}

Categorical variables were reported with frequencies and percentages, and continuous variables were reported with means and standard deviations. Shapiro-Wilk and Brown Forsythe tests were performed to determine the distribution of the variables. To establish the differences between the two groups, we used the Mann-Whitney U test for quantitative variables and the chi-square $\left(\chi^{2}\right)$ test for qualitative variables. The Spearman's rank correlation coefficient was used to identify correlations. Data were analyzed using JMP ver. 9.0 (SAS Institute, Cary, USA) and Stata ver. 11.0 (Stata Corp LP, College Station, USA) statistical software. ${ }^{19}$

\section{Results}

Seventy-five subjects ( $65 \%$ female) aged $17-40$ years (range, $24.0 \pm 7.0$ years) were evaluated. Thirtyfive $(57 \%$ [ $n=20]$ females aged $17-35$ years [range, $20.3 \pm 3.5$ years]) having 35 teeth were diagnosed with healthy pulps, and 40 subjects $(72 \%[n=29]$, aged 17.40 years [range, $27.3 \pm 7.7$ years]) having 40 teeth were diagnosed with irreversible pulpitis. One tooth was included per subject.

Table 1 shows the types of teeth and their clinical evaluation. In the group of teeth having healthy pulps, 35 premolars with apparently healthy crowns were identified. In relation to the group of patients with irreversible pulpitis, the most frequently encountered teeth were mandibular molars ( $\mathrm{n}=17,42 \%)$. Dental caries $(n=30,75 \%)$ was the most common pathology observed in the 40 teeth with pulpitis. The gene, the 
gene of the receptor, and the expression of CGRP in healthy pulps and irreversible pulpitis are presented in Table 2. When we compared the study groups, we found statistically significant differences $(p=$ .0001 ) in the gene, the gene of the receptor, and the expression of CGRP, observing higher values in the group of patients with irreversible pulpitis. Table 3 depicts the expression of CGRP and the responses of the cold test (in seconds) in healthy pulps and irreversible pulpitis. In the group of healthy pulps, on all the seconds of the first time (1-4) and second time (1-3), we observed values of CGRP expression from 3.19-5.19 ng/mL. However, in the group having irreversible pulpitis, at both times, we observed values from $53.7-103 \mathrm{ng} / \mathrm{mL}(\mathrm{p}=.0001)$.

During the first second (second 1) from the application of the stimulus until the participant raised a (his/her) hand (FT), we identified a high frequency of responses using the cold test $(n=22,55 \%)$ and high values of CGRP expression $(103.60 \mathrm{ng} / \mathrm{mL})$. In relation to the ST (from removing the stimulus until the sensation disappeared), a high frequency of

Table 1. Types of teeth and their clinical evaluation $(n=75$ teeth).

\begin{tabular}{lccc}
\hline \multirow{2}{*}{ Jaw } & Teeth & $\begin{array}{c}\text { Healthy pulp } \\
\text { Frequency (\%) }\end{array}$ & $\begin{array}{c}\text { Irreversible } \\
\text { pulpitis }\end{array}$ \\
\cline { 2 - 4 } & & $(\mathrm{n}=35)$ & $(\mathrm{n}=40)$ \\
\hline \multirow{2}{*}{ Maxilla } & Premolars & $26(75)$ & $13(33)$ \\
& Molars & - & $8(20)$ \\
Mandible & Premolars & $9(25)$ & $2(5)$ \\
& Molars & - & $17(42)$ \\
Clinical & Healthy* & $35(100)$ & 0 \\
evaluation & Caries & 0 & $30(75)$ \\
& Restoration & 0 & $17(43)$ \\
& Enamel loss & 0 & $25(63)$ \\
\hline
\end{tabular}

*Apparently healthy crown. responses with the cold test was observed from 4 to $\geq 12 \mathrm{~s}(\mathrm{n}=30,75 \%)$, with values of CGRP expression ranging from $83.00-91.18 \mathrm{ng} / \mathrm{mL}$.

When we compared the expression of CGRP between a group with response to the cold test of $1-3 \mathrm{~s}(\mathrm{n}=45$, [35 healthy pulps and 10 with pulpitis], group 1) and a group of 4 to $\geq 12 \mathrm{~s}$ ( $\mathrm{n}=30$, only pulpitis), group 2), we found statistically significant differences $(P=.0001)$, observing higher values of CGRP expression in the group of responses of 4 to $\geq 12 \mathrm{~s}$ with pulpitis ( $86.20 \pm 51.87$ [range: 21.73-221.63]). On the other hand, CGRP expression in the two groups (healthy group $=0$; irreversible pulpitis group $=1$ ) were associated and correlated. A rho $=0.86$ and $a$ $\mathrm{p}=.0001(\mathrm{n}=75)$ were obtained. We identified an increase of CGRP expression in the pulpitis group.

Response times to the cold test $(1-3 \mathrm{~s}=0$ and $\geq 4=1$ ) of the two study groups (healthy $=0$ and irreversible pulpitis $=1$ ) were also associated and correlated. A rho $=0.76$ and a $p=.0001(n=75)$ were identified. We observed that the responses of the test of $\geq 4 \mathrm{~s}$ was correlated with the diagnosis of irreversible pulpitis. With the previous analyses, we identified that the responses of the cold test between 4 and $\geq 12$ s CGRP had a higher average expression in the irreversible pulpitis group. CGRP expression and the response to an electrical impulse (electric test) in healthy pulps and irreversible pulpitis are demonstrated in Table 4.

In the group of healthy pulps, we observed subjects' responses to electrical impulses ranging from 1-6, with values of CGRP expression between 3.30 and $4.10 \mathrm{ng} / \mathrm{mL}$. In the irreversible pulpitis group, after electrical impulses from 1-10 and without responses to the impulse, we observed values of CGRP expression between 57.86 and $130.25 \mathrm{ng} / \mathrm{mL}$. Sixty percent $(\mathrm{n}=24)$ of the subjects responded to electrical impulses

Table 2. The gene, the gene of the receptor, and the expression of cgrp in healthy pulps and in irreversible pulpitis.

\begin{tabular}{lrr}
\hline Variables & Healthy pulp $(\mathrm{n}=35)$ & Irreversible pulpitis $(\mathrm{n}=40)$ \\
\cline { 2 - 3 } & & Mean \pm SD \\
\hline CGRP Gene (Relative gene expression of CGRP/GAPDH) & $1.12 \pm 0.78$ & $9.77 \pm 5.89^{*}$ \\
Gene of the Receptor (Relative gene expression of CGRP/GAPDH) & $7.24 \pm 5.64$ & $35.03 \pm 17.43^{*}$ \\
CGRP Expression (ng/mL) & $3.97 \pm 2.94$ & $87.75 \pm 43.29^{*}$ \\
\hline
\end{tabular}

CGRP: calcitonin gene-related peptide; SD: standard deviation. ${ }^{*}$ Mann-Whitney $U$ test: $p=0.0001$. 
Expression of calcitonin gene-related peptide and pulp sensitivity tests in irreversible pulpitis

Table 3. Expression of CGRP and responses of cold test in healthy pulps and in irreversible pulpitis.

\begin{tabular}{|c|c|c|c|c|c|}
\hline \multicolumn{3}{|c|}{ Healthy pulps $(\mathrm{n}=35)$} & \multicolumn{3}{|c|}{ Irreversible pulpitis $(n=40)$} \\
\hline Cold Test & First time & $\begin{array}{c}\text { Expression of CGRP } \\
(\mathrm{ng} / \mathrm{mL})\end{array}$ & Cold Test & First time* & $\begin{array}{c}\text { Expression of CGRP } \\
(\mathrm{ng} / \mathrm{mL})\end{array}$ \\
\hline Frequency of response (\%) & (s) & Mean \pm SD & $\begin{array}{l}\text { Frequency of } \\
\text { response (\%) }\end{array}$ & (s) & Mean \pm SD \\
\hline $3(8)$ & 1 & $5.19 \pm 3.1$ & $22(55)$ & 1 & $103.60 \pm 60.6$ \\
\hline $8(23)$ & 2 & $3.19 \pm 2.1$ & $11(28)$ & 2 & $53.73 \pm 31.3$ \\
\hline $22(63)$ & 3 & $3.97 \pm 3.1$ & $2(5)$ & 3 & $88.48 \pm 52.4$ \\
\hline \multirow[t]{3}{*}{$2(6)$} & 4 & $3.23 \pm 2.0$ & $5(12)$ & 4 & $92.53 \pm 25.4$ \\
\hline & Second Time & & & Second Time & \\
\hline & (s) & & & (s) & \\
\hline $4(11)$ & 1 & $3.70 \pm 1.5$ & $3(8)$ & 2 & $78.58 \pm 49.98$ \\
\hline $24(69)$ & 2 & $3.67 \pm 3.0$ & $7(17)$ & 3 & $81.74 \pm 41.20$ \\
\hline \multirow[t]{5}{*}{$7(20)$} & 3 & $4.68 \pm 2.6$ & $7(17)$ & 4 & $83.00 \pm 45.00$ \\
\hline & & & $9(23)$ & $5-6$ & $88.05 \pm 58.91$ \\
\hline & & & $7(17)$ & $7-8$ & $88.29 \pm 60.90$ \\
\hline & & & $3(8)$ & $9-11$ & $89.25 \pm 30.81$ \\
\hline & & & $4(10)$ & $\geq 12$ & $91.18 \pm 42.95$ \\
\hline
\end{tabular}

SD: standard deviation; FT: first time, number of seconds from the application of the stimulus until the participant raised a hand; ST: second time, number of seconds from removing the stimulus until the absence of sensation. *Comparison of the responses in seconds of the FT with the two groups and the ST with both groups was $=0.0001$ (Mann-Whitney U test).

Table 4. Expression of CGRP and response to an electrical impulse (electric test) in healthy pulps and in irreversible pulpitis.

\begin{tabular}{|c|c|c|c|c|c|}
\hline \multicolumn{3}{|c|}{ Healthy pulps $(n=35)$} & \multicolumn{3}{|c|}{ Irreversible pulpitis $(n=40)$} \\
\hline \multirow{2}{*}{ Frequencies (\%) } & \multirow{2}{*}{ Electrical impulse } & $\begin{array}{c}\text { Expression of CGRP } \\
(\mathrm{ng} / \mathrm{mL})\end{array}$ & \multirow{2}{*}{ Frequencies (\%) } & \multirow{2}{*}{ Electrical impulse* } & $\begin{array}{c}\text { Expression of CGRP } \\
(\mathrm{ng} / \mathrm{mL})\end{array}$ \\
\hline & & Mean \pm SD & & & Mean \pm SD \\
\hline $3(9)$ & 1 & $3.65 \pm 2.8$ & $4(10)$ & 1 & $92.93 \pm 20.7$ \\
\hline $6(17)$ & 2 & $4.10 \pm 2.6$ & $7(18)$ & 2 & $83.53 \pm 48.2$ \\
\hline- & - & - & $7(18)$ & 3 & $94.18 \pm 61.9$ \\
\hline $21(60)$ & 4 & $3.95 \pm 3.1$ & $4(10)$ & 4 & $130.25 \pm 74.6$ \\
\hline \multirow[t]{4}{*}{$5(14)$} & 6 & $3.30 \pm 1.4$ & $2(5)$ & 6 & $97.42 \pm 39.7$ \\
\hline & & & $6(15)$ & $7-8$ & $86.45 \pm 60.6$ \\
\hline & & & $5(12)$ & $9-10$ & $57.86 \pm 21.2$ \\
\hline & & & $5(12)$ & Without answer & $74.10 \pm 38.6$ \\
\hline
\end{tabular}

SD: standard deviation; *Comparison of electrical impulses with the two groups was $=p<0.05$ (Mann-Whitney $U$ test).

ranging from 1-6, with a range of $92.93-130.25 \mathrm{ng} / \mathrm{mL}$ of CGRP expression. However, $40 \%$ of the subjects $(n=16)$ either did not respond to the impulse or responded to impulses ranging from 7-10, with a range of $57.86-86.45 \mathrm{ng} / \mathrm{mL}$ of CGRP expression. When we compared the groups ( 35 healthy pulps and 40 irreversible pulpitis) with (a) the presence or absence of response to the test, and (b) the value of the electrical impulse, we found statistically significant differences ( $p=.0001)$, observing, in the group of irreversible pulpitis, the following: a) cases with no sensation and with an average of $74.10 \mathrm{ng} / \mathrm{mL}$ of expression of CGRP, and $b$ ) positive responses to the test with electrical impulses of 7, 8, 9, and 10, with an average of $72.15 \mathrm{ng} / \mathrm{mL}$ of CGRP. On the other hand, responses to the electric test with values of 
1-6 impulses of both groups (healthy pulps [ $\mathrm{n}=35]$ and irreversible pulpitis $[\mathrm{n}=24])$ and the expression of CGRP were compared. We identified statistically significant differences $(p=.0001)$ between the two groups. In the pulpitis group, we observed higher values of CGRP expression (99.66 \pm 50$)$ than those of the healthy group $(3.75 \pm 2.4)$.

\section{Discussion}

The aim of the present study was to identify the relationship between the expression of CGRP and responses of the pulp sensitivity tests in healthy pulps and irreversible pulps; therefore, it was advisable to analyze both variables to find a clinical application that facilitated a more objective result for pulpal diagnosis.

\section{Expression of CGRP in teeth with irreversible pulps}

Whenever the pulp is injured, the immune system triggers an inflammatory response to limit tissue damage by eliminating and digesting invading organisms and cellular debris. Nevertheless, these inflammatory responses can injure pulpal tissue in severe cases and lead to pulpal necrosis. ${ }^{6}$ Pulpitis is a complicated process that involves various nervous and vascular reactions. Neuropeptides are actively involved in homeostatic regulation, both under normal conditions and during pulpitis, by controlling pulpal blood flow and regulating the later stages of inflammatory and reparative processes. ${ }^{1}$ Sensory-derived neuropeptides, such as CGRP, substance $\mathrm{P}$, and neurokinin $\mathrm{A}$, are produced in the trigeminal cell bodies and transported via axons to nerve terminals in the pulp. CGRP, the most powerful endogenous vasodilator, has neurotropic and neurotrophic properties, and it regulates antigen presentation within the immune system. ${ }^{2}$ It is primarily localized at the $\mathrm{C}$ and A- $\delta$ sensory fibers, which display wide innervation throughout the body, but C-type fibers are closely associated with pulp microcirculation. ${ }^{1,20}$

Several studies have reported an increased expression of CGRP on teeth with irreversible pulpitis compared with teeth having healthy pulps. ${ }^{1,3,11,12,21}$ In this study, we observed higher values of the gene, of the gene of the receptor, and of the expression of CGRP in the irreversible pulpitis group $(P=.0001)$. CGRP interacts with mast cells and induces histamine release, which increases vascular permeability and blood pressure. ${ }^{1,12,21}$ CGRP also interacts with other inflammatory cells, such as macrophages and lymphocytes, altering their functions and inducing these cells to release inflammatory mediators such as cytokines, prostaglandins, and thromboxanes, exerting a direct effect on pulp tissue. ${ }^{21}$

\section{Pulp sensitivity tests}

Medical and dental history, clinical examination, specific pulp tests, and a radiographic analysis are necessary for diagnosing pulpitis. ${ }^{4}$ The electric test and the cold test are pulp sensitivity tests frequently performed clinically due to their simplicity and low cost. However, some authors have reported a lack of accuracy, reliability, and reproducibility in these tests. ${ }^{910,14,22,23,24,25}$ Pulp sensitivity tests are based on a subjective response from the patient triggered by an external stimulus (cold, heat, an electrical impulse) from the nervous system. ${ }^{22}$ Therefore, these tests only indicate a neural response from the pulp. ${ }^{4}$ Some authors suggest that pulp sensitivity tests should only be used to assess viable or necrotic pulps because the tests do not quantify pulpal health, pulpal inflammation, or the degree of inflammation. ${ }^{4}$ However, thermal and electric tests, even with their limitations, are useful on diseased pulps because the test responses in diseased pulps are different from those of healthy pulps. ${ }^{4}$

\section{Clinical application of the relationship between the expression of CGRP and the responses of pulp sensitivity tests in healthy pulps and irreversible pulps}

The interrelationships between nervous and vascular reactions and clinical signs and symptoms of pulpitis are complex. ${ }^{5,6,7}$ In the present study, we identified the relationship between the expression of CGRP and the responses of pulp sensitivity tests in healthy pulps and irreversible pulps. We observed that test responses between 4 and $\geq 12 \mathrm{~s}$ 
were associated with high values of CGRP expression on the ST (number of seconds from removing the stimulus until the sensation disappeared) of the cold test in the irreversible pulpitis group $(\mathrm{p}=0.0001)$. In irreversible pulpitis, cold elicits a sharp pain (FT) followed by a dull prolonged ache when the stimulus is removed (ST) ${ }^{4,26}$ Cold causes contraction of the dentinal fluid within the dentinal tubules. This movement results in hydrodynamic forces' acting on the nerve fibers within the pulp-dentin complex. ${ }^{26} \mathrm{~A}-\delta$ fibers mediate sharp pain; $\mathrm{C}$ fibers, dull pain. ${ }^{3,20,27}$ Results of the present study could be useful in clinical practice.

In this study, we discovered that the values 4 to $\geq 12$ s on ST with the cold test were associated with high values of CGRP. Therefore, this parameter might be used as a reference to complement the in-hospital pulpitis diagnosis. The electric test is also a pulp sensitivity test; it delivers a current sufficient to overcome the resistance of enamel and dentin and to stimulate the A- $\delta$ fibers. The nonmyelinated $C$ fibers do not respond to the conventional electric pulp test because significantly more current is needed to stimulate the fibers. A positive response to the electric pulp test is the result of an ionic shift in dentinal fluid within the tubules, causing local depolarization and the subsequent generation of action potential from the nerves. ${ }^{4,28}$

When we compared the groups (healthy pulps and pulpitis) using (1) positive response or absence of response and (2) the value of the electrical impulse, we found statistically significant differences $(p=0.0001)$, obtaining the following results on the group having irreversible pulpitis: a) positive responses to the test with electrical impulses of 7, 8, 9, and 10 with an average of $72.15 \mathrm{ng} / \mathrm{mL}$ of CGRP and b) absence of a response with an average of $74.10 \mathrm{ng} / \mathrm{mL}$ of the expression of CGRP. Health professionals could relate a positive response with electrical impulses from 7-10 with pulpitis because this parameter was identified with high values of CGRP expression on the pulpitis group. We also identified cases having no response to the test (false results) with an average of $74.10 \mathrm{ng} / \mathrm{mL}$ of CGRP expression. Some authors have reported limitations and false results with pulp sensitivity tests, citing these possible causes: a) tests are subjective and measure only nerve responses and not pulp blood flow; b) thermal tests require that the dentinal tubules be open to allow fluid to flow according to the hydrodynamic theory (thus, these tests may not be effective in elderly patients, who are more likely to have teeth with closed tubules and substantial secondary dentin formation); c) electric pulp tests are less reliable in immature traumatized teeth having an open apex; d) reduced neural components of aged pulps provide responses different from those in younger pulps; and (5) extensive restorations, pulp recession, and excessive calcification create limitations in both performing and interpreting pulp test results. ${ }^{4}$

In addition to extensive caries, the following variables are associated with false-positive and false-negative results: periodontal pockets, enamel loss, restorations, and multirooted teeth. ${ }^{4,10,24,28,29,30,31,32}$ We identified $75 \%$ of teeth with caries, $43 \%$ of teeth with restorations, and $63 \%$ of teeth with enamel loss in the molars and premolars of the pulpitis group. It is possible that some of these previously mentioned variables are related to the absence of the electric-test response. Several researches have reported the expression of CGRP in teeth with irreversible pulps. . $^{1,11,12,21,33}$ They have also reported sensitivity, specificity, accuracy, positive predictive value, and negative predictive values of pulp sensitivity tests. ${ }^{4,8,9,10,13,14,15,16,22,23,24,25,26,27,28,29,30,31,32}$ However, after reading some texts, we were unable to find any articles that associated both variables with identifying a clinical use.

\section{Conclusion}

The responses of pulp sensitivity tests presented a higher average of the expression of CGRP in the group having irreversible pulpitis.

\section{Acknowledgments}

Analysis of this work was supported in part by the clinical research laboratory, Program of Doctorate in Dental Sciences, University of San Luis Potosí, Mexico. Publication was supported by the Ministry of Education, Mexican Federal Government, through the Faculty Development Program. 
Castillo-Silva BE, Martínez-Jiménez V, Martínez-Castañón GA, Medina-Solís CE, Aguirre-López EC, Castillo-Hernández JR et al.

\section{References}

1. Sattari M, Mozayeni MA, Matloob A, Mozayeni M, Javaheri HH. Substance P and CGRP expression in dental pulps with irreversible pulpitis. Aust Endod J. 2010 Aug;36(2):59-63. https://doi.org/10.1111/j.1747-4477.2009.00186.x

2. Tsatsaris V, Tarrade A, Merviel P, Garel JM, Segond N, Jullienne A, et al. Calcitonin gene-related peptide (CGRP) and CGRP receptor expression at the human implantation site. J Clin Endocrinol Metab. 2002 Sep;87(9):4383-90. https://doi.org/10.1210/jc.2002-020138

3. Caviedes-Bucheli J, Moreno GC, López MP, Bermeo-Noguera AM, Pacheco-Rodríguez G, Cuellar A, et al. Calcitonin generelated peptide receptor expression in alternatively activated monocytes/macrophages during irreversible pulpitis. J Endod. 2008 Aug;34(8):945-9. https://doi.org/10.1016/i.joen.2008.05.011

4. Jafarzadeh H, Abbott PV. Review of pulp sensibility tests. Part I: general information and thermal tests. Int Endod J. 2010 Sep;43(9):738-62. https://doi.org/10.1111/j.1365-2591.2010.01754.x

5. Hirsch V, Wolgin M, Mitronin AV, Kielbassa AM. Inflammatory cytokines in normal and irreversibly inflamed pulps: A systematic review. Arch Oral Biol. 2017 Oct;82:38-46. https://doi.org/10.1016/i.archoralbio.2017.05.008

6. Rechenberg DK, Galicia JC, Peters OA. Biological Markers for Pulpal Inflammation: A Systematic Review. PLoS One. 2016 Nov;11(11):e0167289. https://doi.org/10.1371/journal.pone.0167289

7. Zanini M, Meyer E, Simon S. Pulp Inflammation Diagnosis from Clinical to Inflammatory Mediators: A Systematic Review. J Endod. 2017 Jul;43(7):1033-51. https://doi.org/10.1016/i.joen.2017.02.009

8. Dastmalchi $\mathrm{N}$, Jafarzadeh $\mathrm{H}$, Moradi S. Comparison of the efficacy of a custom-made pulse oximeter probe with digital electric pulp tester, cold spray, and rubber cup for assessing pulp vitality. J Endod. 2012 Sep;38(9):1182-6. https://doi.org/10.1016/i.joen.2012.06.012

9. Weisleder R, Yamauchi S, Caplan DJ, Trope M, Teixeira FB. The validity of pulp testing: a clinical study. J Am Dent Assoc. 2009 Aug;140(8):1013-7. https://doi.org/10.14219/jada.archive.2009.0312

10. Villa-Chávez CE, Patiño-Marín N, Loyola-Rodríguez JP, Zavala-Alonso NV, Martínez-Castañón GA, Medina-Solís CE. Predictive values of thermal and electrical dental pulp tests: a clinical study. J Endod. 2013 Aug;39(8):965-9. https://doi.org/10.1016/i.joen.2013.04.019

11. Caviedes-Bucheli J, Lombana N, Azuero-Holguín MM, Munoz HR. Quantification of neuropeptides (calcitonin gene-related peptide, substance $P$, neurokinin $A$, neuropeptide $Y$ and vasoactive intestinal polypeptide) expressed in healthy and inflamed human dental pulp. Int Endod J. 2006 May;39(5):394-400. https://doi.org/10.1111/j.1365-2591.2006.01093.x

12. Caviedes-Bucheli J, Camargo-Beltrán C, Gómez-la-Rotta AM, Moreno SC, Abello GC, González-Escobar JM. Expression of calcitonin gene-related peptide (CGRP) in irreversible acute pulpitis. J Endod. 2004 Apr;30(4):201-4. https://doi.org/10.1097/00004770-200404000-00004

13. Fuss Z, Trowbridge H, Bender IB, Rickoff B, Sorin S. Assessment of reliability of electrical and thermal pulp testing agents. J Endod. 1986 Jul;12(7):301-5. https://doi.org/10.1016/S0099-2399(86)80112-1

14. Chen E, Abbott PV. Evaluation of accuracy, reliability, and repeatability of five dental pulp tests. J Endod. 2011 Dec;37(12):1619-23. https://doi.org/10.1016/i.joen.2011.07.004

15. Udoye $\mathrm{Cl}$, Jafarzadeh H, Okechi UC, Aguwa EN. Appropriate electrode placement site for electric pulp testing of anterior teeth in Nigerian adults: a clinical study. J Oral Sci. 2010 Jun;52(2):287-92. https://doi.org/10.2334/josnusd.52.287

16. Lin J, Chandler N, Purton D, Monteith B. Appropriate electrode placement site for electric pulp testing first molar teeth. J Endod. 2007 Nov;33(11):1296-8. https://doi.org/10.1016/i.joen.2007.08.006

17. Uddman R, Kato J, Lindgren P, Sundler F, Edvinsson L. Expression of calcitonin gene-related peptide-1 receptor mRNA in human tooth pulp and trigeminal ganglion. Arch Oral Biol. 1999 Jan;44(1):1-6. https://doi.org/10.1016/S0003-9969(98)00102-2

18. Man TK, Li Y, Dang TA, Shen J, Perlaky L, Lau CC. Optimising the use of TRlzol-extracted proteins in surface enhanced laser desorption/ ionization (SELDI) analysis. Proteome Sci. 2006 Mar;4(1):3. https://doi.org/10.1186/1477-5956-4-3

19. Lin LI. A concordance correlation coefficient to evaluate reproducibility. Biometrics. 1989 Mar;45(1):255-68. https://doi.org/10.2307/2532051

20. Russell FA, King R, Smillie SJ, Kodji X, Brain SD. Calcitonin gene-related peptide: physiology and pathophysiology. Physiol Rev. 2014 Oct;94(4):1099-142. https://doi.org/10.1152/physrev.00034.2013

21. Caviedes-Bucheli J, Arenas N, Guiza O, Moncada NA, Moreno GC, Diaz E, et al. Calcitonin gene-related peptide receptor expression in healthy and inflamed human pulp tissue. Int Endod J. 2005 Oct;38(10):712-7. https://doi.org/10.1111/j.1365-2591.2005.01006.x

22. Jespersen JJ, Hellstein J, Williamson A, Johnson WT, Qian F. Evaluation of dental pulp sensibility tests in a clinical setting. J Endod. 2014 Mar;40(3):351-4. https://doi.org/10.1016/i.joen.2013.11.009

23. Gopikrishna V, Tinagupta K, Kandaswamy D. Comparison of electrical, thermal, and pulse oximetry methods for assessing pulp vitality in recently traumatized teeth. J Endod. 2007 May;33(5):531-5. https://doi.org/10.1016/i.joen.2007.01.014 
24. Alghaithy RA, Qualtrough AJ. Pulp sensibility and vitality tests for diagnosing pulpal health in permanent teeth: a critical review. Int Endod J. 2017 Feb;50(2):135-42. https://doi.org/10.1111/iej.12611

25. Peters DD, Baumgartner JC, Lorton L. Adult pulpal diagnosis. I. Evaluation of the positive and negative responses to cold and electrical pulp tests. J Endod. 1994 Oct;20(10):506-11. https://doi.org/10.1016/S0099-2399(06)80048-8

26. Gopikrishna V, Pradeep G, Venkateshbabu N. Assessment of pulp vitality: a review. Int J Paediatr Dent. 2009 Jan;19(1):3-15. https://doi.org/10.1111/j.1365-263X.2008.00955.x

27. Levin LG, Law AS, Holland GR, Abbott PV, Roda RS. Identify and define all diagnostic terms for pulpal health and disease states. J Endod. 2009 Dec;35(12):1645-57. https://doi.org/10.1016/i.joen.2009.09.032

28. Jafarzadeh H, Abbott PV. Review of pulp sensibility tests. Part Il: electric pulp tests and test cavities. Int Endod J. 2010 Nov;43(11):94558. https://doi.org/10.1111/j.1365-2591.2010.01760.x

29. Nitzan DW, Michaeli Y, Weinreb M, Azaz B. The effect of aging on tooth morphology: a study on impacted teeth. Oral Surg Oral Med Oral Pathol. 1986 Jan;61(1):54-60. https://doi.org/10.1016/0030-4220(86)90203-3

30. Chunhacheevachaloke E, Ajcharanukul O. Effects of conducting media and gender on an electric pulp test. Int Endod J. 2016 Mar;49(3):237-44. https://doi.org/10.1111/iej.12446

31. Farac RV, Morgental RD, Lima RK, Tiberio D, dos Santos MT. Pulp sensibility test in elderly patients. Gerodontology. 2012 Jun;29(2):1359. https://doi.org/10.1111/i.1741-2358.2012.00623.x

32. Rutsatz C, Baumhardt SG, Feldens CA, Rösing CK, Grazziotin-Soares R, Barletta FB. Response of pulp sensibility test is strongly influenced by periodontal attachment loss and gingival recession. J Endod. 2012 May;38(5):580-3. https://doi.org/10.1016/i.joen.2012.01.011

33. Awawdeh L, Lundy FT, Shaw C, Lamey PJ, Linden GJ, Kennedy JG. Quantitative analysis of substance P, neurokinin A and calcitonin gene-related peptide in pulp tissue from painful and healthy human teeth. Eur J Oral Sci. 2002 Jun;110(3):185-91. https://doi.org/10.1034/j.1600-0447.2002.21236.x 